\title{
Design and management of an orthopaedic bone bank in the Netherlands
}

\author{
Eline W. Zwitser - Timothy U. Jiya • \\ H. George Licher • Barend J. van Royen
}

Received: 7 June 2010/Accepted: 2 November 2010/Published online: 13 November 2010

(C) The Author(s) 2010. This article is published with open access at Springerlink.com

\begin{abstract}
The design and management of an orthopaedic bone bank is a complex process in which medical organisation and legislation intertwine. Neither in the Netherlands, nor in any other European country, there are official guidelines for the organisation and management of an orthopaedic bone bank. In the Netherlands, the recently modified 'law of security and quality for using human materials' (WVKL) dictates requirements for technical and organisational aspects for the use of human tissue and cells. The bone bank procedures include a thorough questionnaire for donor selection, extensive serological, bacteriological and histopathological examination, as well as standard procedures for registration, processing, preservation, storage and distribution of bone allografts. This article describes the organisation of an accredited bone bank and can be used as a proposition for an official guideline or can be useful as an example for other orthopaedic bone banks in Europe.
\end{abstract}

Keywords Orthopaedic bone bank · Legislation . Organization

E. W. Zwitser - T. U. Jiya · H. George Licher .

B. J. van Royen $(\varangle)$

Department of Orthopaedic Surgery, VU University

Medical Center, De Boelelaan 1117, 1081 HV

Amsterdam, The Netherlands

e-mail: bj.vanroyen@vumc.nl

\section{Introduction}

For reconstruction of bone defects, donor bone from orthopaedic bone banks is often necessary. Bone grafts are used in bone defects that arise from trauma (Friedlaender 1987), infection, resection of bone tumours (Mankin et al. 1996) or it is used in spinal fusion (Raizman et al. 2009) and as impaction grafting in revision of total joint arthroplasty (Slooff et al. 1996).

Autologous bone is preferred because of its osteoconductive and osteoinducive activity, but it is often not sufficiently available and it repeatedly involves donor site morbidity (Summers and Eisenstein 1989). Allogenic bone exclusively has osteoconductive activity; it serves as a frame against which newly formed bone gets deposited (Elves and Pratt 1975; Urist 1953). Allogenic bone is provided by an orthopaedic bone bank.

In Leiden, the Netherlands, the Dutch Bone Bank Foundation (NBF) was founded in 1988 (Veen et al. 1990). In this central bone bank, bone- and tendon transplant material of deceased donor patients is stored (Veen et al. 1991). When needed, hospitals may order such material from the NBF.

A number of hospitals manage their own bone banks, such as the VU university medical center in Amsterdam, where an orthopaedic bone bank has been established. This VUmc orthopaedic bone bank contains only femoral heads of suitable patients who underwent total hip replacement surgery. The 
advantage of possessing a bone bank is that the hospital always has its own supply of donor bone material; this may also be a financially viable strategy for hospitals carrying out many procedures for which donor bone material is required.

Up to now, nationally recognized guidelines for maintenance and management of bone banks do not yet exist in the Netherlands. In this paper we describe the VUmc orthopaedic bone bank procedure, which recently gained official approval and recognition and could serve as a potential outline for other hospitals.

\section{Bone bank procedure}

From October 2008, the Ministry of Health, Welfare and Sport (VWS) officially recognized the orthopaedic bone bank of the VUmc (Inspectie voor de Gezondheidszorg 2008). A biannual inspection is performed by the Health Care Inspectorate (IGZ) as a requirement to maintain this recognition. The bone bank procedure has to meet the requirements of the adjusted 'law of security and quality for using human materials' (Wet Veiligheid en Kwaliteit Lichaamsmateriaal 2003). This law became effective from mid-2007 in the Netherlands as a result of European guidelines 2004/23/EC and 2006/86/EC. These guidelines state the technical requirements for coding, processing, preserving, storing, and distributing of human tissue and cells. Human tissue should be traceable, and serious side effects and incidents with human tissue and cells should be reported.

The procedure of our orthopaedic bone bank is based on guidelines of The American Association of Tissue Banks (AATB), and the criteria of the Council for Blood Transfusion of the Netherlands Red Cross (Richtlijn Bloedtransfusie 2004), together with the recently merged Netherlands Bone Bank Foundation (NBF) and Bio Implant Services (BIS) (NBF-BIS Foundation 2010).

Previously, we followed the guidelines of the European Association of Musculoskeletal Transplantation. As a result of diverging European legislations, this organization has been discontinued as an European umbrella organization; currently only national associations prevail. To date, the Netherlands has not possessed such an association; consequently there is no national guideline with regards to maintenance and management of an orthopaedic bone bank.

\section{The bone bank protocol}

The bone bank procedure should be carefully described in an extensive protocol consisting of the following five components: organization, donor selection, documentation, storage and processing, and implementation. The HOD (Head of Department) of the Department of Orthopaedics and the bone bank administrator compose this protocol.

\section{Organization}

In an organization chart we describe the responsibilities of different stakeholders: the HOD of the Department of Orthopaedics, a bone bank administrator, a theatre nurse, a medical microbiologist, an anatomic pathologist, a clinical chemical analyst, a haematological laboratory technician, and a trainer. The HOD is the main responsible of the bone bank, whereas the bone bank administrator is responsible for the daily management. The knowledge and skills concerning surgical techniques and clinical hygiene are guaranteed by the orthopaedic surgeon and theatre nurse. The bone bank administrators' responsibilities include administration as well as storage and allocation of donor bone. Additionally, the administrator takes care of the maintenance and cleaning of the storage facilities (freezers, etc.), and verifies the registration forms of femoral heads meeting the requirements for storage in the bone bank. Both the bone bank administrator and the trainer are responsible for training of bone bank employees.

Apart from an orientation module for new employees, the training program consists of regular refresher courses for all members of the staff, in order to keep the knowledge of the procedures updated.

\section{Donor selection}

Preceding the hip replacement procedure, the attending orthopaedic surgeon requests the patient for his permission to store any removed tissue for donation. It concerns patients whose femoral head grafts will be retrieved in order to be replaced by a total hip prosthesis. Corticospongious bone tissue can not be sufficiently obtained in knee or shoulder arthroplasty; therefore patients undergoing such procedures cannot be taken into consideration for donor bone tissue donation. 
The attending orthopaedic surgeon informs the patient both orally and in written. In case the patient grants permission he or she signs the consent forms, and fills out a standard survey (see Table 1). The orthopaedic surgeon now decides whether the patient is suitable for being a donor; he uses general and specific exclusion criteria (see Tables 2,3). All criteria must be met; if not, exclusion necessarily follows. The orthopaedic surgeon examines the patient thoroughly: blood samples are collected to determine blood type, Rh-factor and erythrocyte sedimentation rate (ESR) (Tables 4, 5).

During surgery, bacterial culture swab samples from hip ligament are collected and a biopsy of corticospongious bone is sent off for histopathological analysis. Serological screening for infectious diseases is performed 6 months after surgery. Once all requirements are met (Tables 1, 2, 3, 4, 5), a femoral head can be released for donation:

- approval donor

- signed consent forms of donor

- completed survey; all questions should yield a negative answer

- preoperative ESR rates within criteria

- no abnormal bacteriological values in surgery derived tissue

- no abnormal histopathological structures in surgery derived tissue

- no abnormal serological values 6 months after surgery

Table 1 Questionnaire patient for orthopaedic bone donation

In the past 3 months, did you suffer any infection? If so, what infection?

In the past 3 months, did you have any vaccination or inoculation, or have you been injected with narcotic drugs?

In the past 6 months, did you have a malaria attack or did you use anti-malarial medication?

Have you ever been infected with a sexually transmitted disease?

Have you ever been diagnosed with jaundice or liver illness?

In the past 6 months, have you been in contact with patients diagnosed with jaundice/hepatitis?

In the past 6 months, have you been in contact with patients diagnosed with AIDS, or individuals at risk to AIDS? If yes, how and when?

Have you ever been tested for HIV/AIDS?

Have you had homosexual intercourse after 1977? (males only)

Have you emigrated after 1977? If so, to what country?

Are you diagnosed with haemophilia? If yes, are you using anticoagulants?

Are you a sexual partner of an individual for which any of the abovementioned questions can be answered with 'yes'?

Have you been actively involved in prostitution after 1977, or have you been a sexual partner of a person involved in prostitution in the past 6 months?

Have you ever been diagnosed with a haematological disease or any malignant disorder?

Have you ever been treated for diabetes mellitus?

Have you ever been treated for chronic brain- or neurological diseases?

Have you ever received radiation therapy?

Have you ever been diagnosed with rheumatoid arthritis?

Have you ever been diagnosed with tuberculosis?

Have you ever been diagnosed with any disease, other than the abovementioned?

Have you ever received hormonal treatment?

Do you use any prescribed medication?

Have you ever used any narcotic drugs?

Have you recently been exposed to hazardous or toxic materials? If yes, please specify.

What is your alcohol consumption per week?

Have you recently been in surgery? If so, when? Did you receive blood from a blood transfusion?

In the past 14 days, have you been traveling through or staying in a region exposed to a SARS epidemic, or have you been in contact with patients infected with SARS?

In the past 6 months, have you tattooed yourself or did you get a piercing? 
Table 2 General exclusion criteria

No permission from patient

Under aged donor $(<18$ years $)$

Active or recent systemic infection/sepsis

Active infection of transplantation tissue (especially coxitis/osteomyelitis)

Previously infected with tuberculosis

Active "slow-virus" infection or anamnesis in the past

Anamnesis of previous infection with hepatitis B or C, AIDS or AIDS related complex, or tested positive for HIV

Active or past syphilis infection

Recent ( $<4$ weeks) vaccination with live vaccine (measles, yellow fever, mumps, polio, oral typhoid, rubella)

Rheumatoid arthritis

Diffuse connective tissue disorders/autoimmune diseases

Metabolic disorders

Existing insulin dependent diabetes mellitus

Treatment with growth hormones

Chronic medication (especially corticosteroids)

Recent exposure to toxic substances

Malignancies

Donor location has been exposed to radiation

Chronic neurological disorders

Dementia

Language barrier or when patient does not understand the information for any reason (e.g. psychiatric patients)

Table 3 Specific exclusion criteria

A clinically proven HIV infection

Men having homosexual intercourse after 1977

Intravenous medication/narcotics use, currently or in the past

Immigrants (after 1977) from countries of which it is known that heterosexual intercourse is an important factor for HIV transmission

Haemophilic patients administered with clotting factors concentrate

Sexual partners from abovementioned individuals

Men and women active in prostitution since 1977, and individuals being their partner in the past 6 months

Individuals who recently (past 6 months) placed a tattoo or piercing

Individuals who have had a blood transfusion before 1980

Individuals who have had a blood transfusion outside Europe or North America

Individuals who stayed in a SARS epidemic area or individuals who had face-to-face contact with a SARS patient

\section{Documentation}

Accurate documentation and coding are a necessity for a well functioning bone bank. A unique registration code is allocated to each femoral head. Only the bone bank administrator is able to trace the donor based on this code. Of every registered femoral head, a file, containing the consent forms and results of ESR, bacteriological and histopathological examination, is kept updated. Other relevant data, such as the size of the femoral head and the allocation date are also documented and stored in this file. When the file is completed (which takes at least 6 months due to the serological examination), and no abnormalities are recorded, both bone bank administrator and the responsible orthopaedic surgeon sign the forms. The femoral head is now available for transplantation. In case a file cannot be completed in full, or any 
Table 4 Haematological examination before surgery

\begin{tabular}{l} 
Blood type and rhesus factor \\
\hline Erythrocyte sedimentation rate (ESR), age and sex \\
dependant \\
Normal values \\
Male \\
$\quad<50$ years: $0-15$ \\
$>50$ years: $0-20$ \\
Female \\
$<50$ years: $0-20$ \\
$>50$ years: $0-30$ \\
\hline
\end{tabular}

Table 5 Serological examination 6 months postoperative

\begin{tabular}{l}
\hline Viral (hepatitis) \\
Hepatitis B antigen \\
Hepatitis B antibody \\
Hepatitis C antibody \\
Viral nucleic acid \\
Viral (additional) \\
HIV \\
HTLV \\
Bacterial syphilis \\
TPHA
\end{tabular}

abnormal values are recorded, the femoral head will be destroyed according to hospitals' protocol.

\section{Storage and processing}

The femoral head is surgically removed under sterilized conditions. The ligament and synovial tissue are cultured on aerobic and anaerobic bacteria. In order to exclude malignancies, auto-immune processes, or infections, a biopsy of $1 \mathrm{~cm}^{3}$ corticospongious bone and ligament is collected for histopathological examination. After determining its size, the femoral head is wrapped in a sterile plastic bag and in three layers parcelled in sterile packing material, labelled and stored in the freezer within $30 \mathrm{~min}$.

The freezer has a temperature of $-80^{\circ} \mathrm{C}$, and has a continuous temperature registration device installed. Should the temperature fall outside the acceptable range of -90 and $-70^{\circ} \mathrm{C}$, an alarm system gives off a warning signal to the Technical Service, guaranteeing a 24-h security against temperature-induced damage to the tissue. A nitrogen tank is fitted onto the freezer, as a backup cooling mechanism in case of mechanical breakdown of the freezer. In deep frozen condition, the allogenic bone tissue can be preserved for a maximum of 5 years. The temperature data is stored and managed by the bone bank administrator for a period of at least 5 years.

\section{Allocation and implementation}

If during surgery a surgeon decides to use a femoral head as an allograft, a femoral head from the freezer together with its documents are handed over to the orthopaedic surgeon and surgery team. The orthopaedic surgeon and theatre nurse verify the file and expiration date of the femoral head. The femoral head is thawed in physiological saline; after being defrosted the theatre nurse takes a bacterial culture swab.

The hospital or care institution warrant fulfilment of the traceability requirements, which implies storing the file of the femoral head and records of the receiving patient for 30 years post implantation.

\section{Discussion}

Macewen first describes the use of allogenic human bone tissue in 1881 (Macewen 1881). From that year onwards, the use of allogenic bone transplantation has been increasingly applied and is nowadays a standard orthopaedic procedure (Tomford et al. 1987). However, much has changed in the past decade: donor selection, clinical hygiene, storage and processing, allocation, implantation, and documentation are bound to strict rules.

Donor selection takes place by a thorough broad survey and supplementary physical examination. The survey should be regularly revised to comprise the latest knowledge and developments, and as a response to the spread of new infectious diseases. For instance, after the outbreak of the SARS epidemic in certain countries, a question was added to the survey; prospective donors were asked whether they had been in SARS-infected regions or whether they had been in contact with an infected person. It is not unthinkable that newly arising infectious diseases will be included in the survey and henceforth become exclusion criteria. 
Laboratory examination is performed before surgery, including ESR determination. Elevated values are often encountered, often without clinical implications. However, the exclusion criteria are strictly enforced. Preoperatively, blood type and Rh-factor are determined. The Rh-factor only becomes an issue if the receiving patient is a young woman. Additionally, the donor is serologically examined, to exclude possible transmission of infections, such as HIV and hepatitis (Strong et al. 1996; Shutkin 1954; Patel and Trampuz 2004; Karcher 1997). The serological tests are carried out at least 6 months after surgery to avoid type II error (false negative): if the patient was infected at the time of surgery, the test will provide conclusive evidence of this. Normally, the donor will not be informed of the results, unless specifically requested by the donor.

In addition to existing national and international guidelines and procedures of the AATB, NBF-BIS, and former EAMST, histopathological examination is added to the current bone bank procedure. Previous studies have found pathological abnormalities in $8 \%$, and B-cell lymphomas in 2,2\% of donor femoral heads (Palmer et al. 1999; Zwitser et al. 2009; Sugihara et al. 1999). Though transmission of malign cells following transplantation has never been shown, femoral heads with histopathological abnormalities are excluded from allogenic bone transplantation.

Apart from an orthopaedic bone bank, many hospitals often have more organ banks, such as a haematological bone marrow bank for stem cell transplantation or the IVF laboratory of the department of Gynaecology and Obstetrics. Therefore, in every hospital a central system for tissue vigilance should be established and all departments that require cells and/or tissue for transplantation purposes should participate. Thus, highest cell and tissue security levels within the hospital are warranted by controlling the complete transplantation chain from donation to transplantation, including appropriate reporting and follow-up of incidents and side effects.

\section{Conclusions}

The design and management of an orthopaedic bone bank as an organ bank is a very complex process in which aspects of medical organization and legislation intertwine. In this paper we describe our bone bank procedure, which is approved and recognized by the Ministry of Health, Welfare and Sport (VWS) of the Netherlands. This procedure could serve as a provisional Dutch protocol for the setup and maintenance of other orthopaedic bone banks.

Acknowledgments In particular, we would like to thank Robert J. Lensen and Janna van der Zedde for their advises and help in preparing this manuscript.

Open Access This article is distributed under the terms of the Creative Commons Attribution Noncommercial License which permits any noncommercial use, distribution, and reproduction in any medium, provided the original author(s) and source are credited.

\section{References}

American Association of Tissue Banks (AATB) (1993) Standards for tissue banking. http://www.aatb.org

Elves MW, Pratt LM (1975) The pattern of new bone formation in isografts of bone. Acta Orthop Scand 46:549-560

Friedlaender GE (1987) Bone grafts. The basic science rationale for clinical applications. J Bone Joint Surg Am 69:786-790

Inspectie voor de Gezondheidszorg (2008) http://www.igz.nl/ zoeken/document.aspx?doc=VUMC_Botbank_Amsterdam_ oktober_2008 (in Dutch)

Karcher HL (1997) HIV transmitted by bone graft. BMJ 314:1300

Macewen W (1881) Observations concerning transplantation on bone. Proc R Soc Lond 32:232-246

Mankin HJ, Gebhardt MC, Jennings LC, Springfield DS, Tomford WW (1996) Long-term results of allograft replacement in the management of bone tumors. Clin Orthop Relat Res 324:86-97

NBF-BIS Foundation (2010) http://www.bisfoundation.org

Palmer SH, Gibbons CL, Athanasou NA (1999) The pathology of bone allograft. J Bone Joint Surg Br 81:333-335

Patel R, Trampuz A (2004) Infections transmitted through musculoskeletal-tissue allografts. $\mathrm{N}$ Engl J Med 350: 2544-2546

Raizman NM, O'Brien JR, Poehling-Monaghan KL, Yu WD (2009) Pseudarthrosis of the spine. J Am Acad Orthop Surg 17:494-503

Richtlijn Bloedtransfusie (2004) Kwaliteitsinstituut voor de Gezondheidszorg CBO. http://www.cbo.nl/thema/Richtlijnen/ Overzicht-richtlijnen/Overig/ (in Dutch)

Shutkin NM (1954) Homologous-serum hepatitis following the use of refrigerated bone-bank bone. J Bone Joint Surg Am 36-A(1):160-162

Slooff TJ, Buma P, Schreurs BW, Schimmel JW, Huiskes R, Gardeniers J (1996) Acetabular and femoral reconstruction with impacted graft and cement. Clin Orthop Relat Res 324:108-115

Strong DM, Friedlaender GE, Tomford WW, Springfield DS, Shives TC, Burchardt H, Enneking WF, Mankin HJ 
(1996) Immunologic responses in human recipients of osseous and osteochondral allografts. Clin Orthop Relat Res 326:107-114

Sugihara S, van Ginkel AD, Jiya TU, van Royen BJ, van Diest PJ, Wuisman PI (1999) Histopathology of retrieved allografts of the femoral head. J Bone Joint Surg $\mathrm{Br}$ 81:336-341

Summers BN, Eisenstein SM (1989) Donor site pain from the ilium. A complication of lumbar spine fusion. J Bone Joint Surg Br 71:677-680

Tomford WW, Mankin HJ, Friedlaender GE, Doppelt SH, Gebhardt MC (1987) Methods of banking bone and cartilage for allograft transplantation. Orthop Clin North Am 18:241-247

Urist MR (1953) Physiologic basis of bone-graft surgery; with special reference to the theory of induction. Clin Orthop $1: 207-216$
Veen MR, Bloem RM, Persijn GG (1990) A central bone bank for bone transplantation. Ned Tijdschr Geneeskd 134: 988-992

Veen MR, Rietveld DC, Bloem RM (1991) The use of allogeneic bone and tendon tissue from a central bone bank. Ned Tijdschr Geneeskd 135:2028-2031

Wet Veiligheid en Kwaliteit Lichaamsmateriaal (2003) http:// wetten.overheid.nl/BWBR0014682/geldigheidsdatum_0306-2010 (in Dutch)

Zwitser EW, de Gast A, Basie MJ, van Kemenade FJ, van Royen BJ (2009) B-cell lymphoma in retrieved femoral heads: a long term follow up. BMC Musculoskelet Disord $10: 53$ 